\title{
PROBLEMS AND PERSPECTIVES OF DEVELOPMENT OF RELIGIOUS TOURISM IN THE REPUBLIC OF MOLDOVA
}

\author{
Slobodzean Anastasia, ASEM, willwandom99@mail.ru, \\ Coordinator Todoroi Dumitru, ASEM, todoroi@ase.md
}

\begin{abstract}
Scope of work: justification of development strategies for the cultural religious tourism, harmonization of the interests of religious cultural institutions and management of economic agents providing special and general services. Design/methodology/ approach: the work shows the strengths, weaknesses, threats and opportunities of religious tourism in the Republic of Moldova providing for the continued discussions as to the further development of this domain. Statements: based on the performed analysis one may conclude that the religious tourism is a quite important branch of tourism in the Republic of Moldova, as the monasteries are the main tourist attractions in the country. Limitations / research suggestions: this work considers the discussions relating to the position of religious tourism in the Republic of Moldova and offers several methods and development methods. Applied value: the results of this work are upheld by the value of useful statements, conclusions and recommendations: studies in the manner of cultural religious tourism, didactical staff in public and private education, editing of scientific-didactical works. The work may be useful for the students in mastering and examining the dimensions of cultural religious tourism, for the tourist agencies practicing this form of tourism, for the statistical analysis and prognoses, as well as for the determination of new development directions of tourism in the Republic of Moldova. Scientific novelty and originality: the need to justify new forms of tourism and their integration into the offers of specialized tourist agencies; elaboration of development plans and diversification of tourist offers in collaboration with all institutions. Conclusions and perspectives: the submitted results represent a logical continuation of research performed under the Project „Anti-migration management in the rural sector of the Republic of Moldova".
\end{abstract}

Keywords: strategy, accommodation structures, competition, religious tourism, anti-migration management

\section{Introduction}

Religious tourism is a motivational form of tourism is aimed at visiting cultural objects and points of interest with or without divine services. Religious tourism implies a higher cultural level of tourists capable of appreciating the visited objects from the point of view of architecture, history and architecture, as well as their spiritual and religious significance. Religious tourism is an important sector of global economy with a tendency of permanent growth at international level. The tourist industry covers a wide range of public and private institutions, generators of economic and social benefits, of new jobs for various categories of employees, offering employment opportunities, especially for women. The Republic of Moldova must be promoted efficiently as a tourist destination on the international tourist markets, raising thus its degree of competitiveness.

Scope of work: justification of development strategies for the cultural religious tourism, harmonization of the interests of religious cultural institutions and tourist management of economic agents providing special and general services.

\section{Design / methodology/ approach:}

\section{SWOT analysis of tourism}

\section{Strengths (S)}

1. Positioning of tourism as a priority branch of economy of the Republic of Moldova

2. Availability of natural and artificial tourist resources

3. Existence of legal and normative framework

4. Implementation of tourism projects with 
financing from state budget

5. Implementation of strategies and development programs in various districts

6. Availability of modern accommodation and boarding structures

7. Existence of conference halls with modern equipment

8. Existence of 3 professional development centers for the persons employed in the tourism industry

9. Activity of various specialty associations

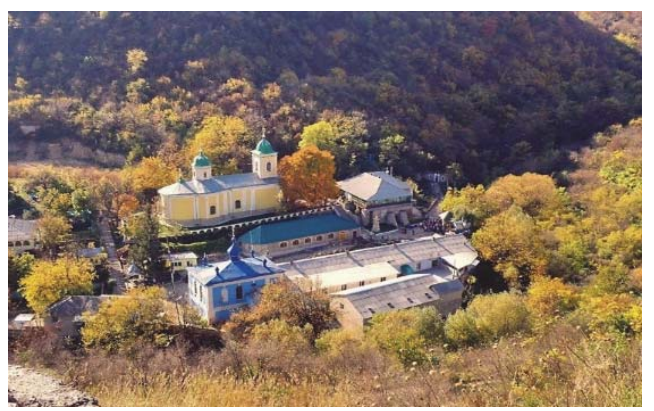

Saharna Monastery, Rezina region

10. The Republic of Moldova is member of international organizations supporting the development of tourism (the UN Global Tourism Organization, the Danube Competence Center, the Black Sea Economic Cooperation Organization, the CIS Tourism Council, etc.)

\section{Weaknesses (W)}

1. The legislation is not aligned to the European standards

2. Insufficient legal and normative framework

3. Insufficiency of qualified staff in the management of branch and provision of quality services

4. The institutional framework needs the implementation of relevant state policies at the central level

5. Lack of Tourist Information Office and its branches in the diplomatic missions of the Republic of Moldova accredited abroad

6 . The limited number of tour operators and agencies establishing and selling national tourist products.

7. Insufficiency of 2-3 star hotels that would contribute to the development of tourism receptive to attractive costs, competitive on the international market

8. High accommodation costs in the national objects

9. Small number of accommodation facilities in the rural area

10. Small number of classified accommodation facilities

11. Insufficiency of indicators for tourists

12. Lack of informational boards in the proximity of tourist attractions

13. Lack of specially equipped places for camping

14. Old fleet of tourist buses

15. Lack of staff with knowledge of internationally spoken languages at the most of tourist objects and museums

16. The statistical figures are calculated erroneously and do not reflect the real situation in the domain

17. The individual tourists are not accounted by the statistics

18. Low efficiency of the mechanism of control over the quality of rendered tourist services

\section{Opportunities (O)}

1. Traditional hospitality

2. Favorable strategic positioning of country (borders with CIS and European Union)

3. No need for visas for the citizens of EU countries, USA, Japan

4. Smaller number of countries with a raised migration risk status, bearing in mind the list approved by the European Union

5. Airway connections with the major airports

6. Liberalization of prices for the air tickets and de-monopolization of air transportation

7. Existence of external assistance projects for the development of tourism

8. Numerous events of interest for tourists: cultural-artistic, sports, entertainment

9. Known brand of winemaking country

10. Existence of unique winemaking and wine tasting facilities

11. Massive spreading of information technology and communications in the sphere of services

12. Existence of political support.

\section{Threats (T)}

1. Weakly developed infrastructure at the tourist facilities of national and international level

2. Low level of recognizability of Moldova as a tourist destination in Europe and in the world

3. Lack of favorable investment climate for the 
investors in tourist infrastructure with accommodation and boarding functions for mass tourism

4. Reduced competitiveness of the tourist offer of the Republic of Moldova (high entry visa costs for the Republic of Moldova, high air transportation costs provided by the national airway companies)

5. Extremely limited number of objects included into the UNESCO patrimony list and the Guinness Record Book

6. Insufficiency of financial resources for promotion: exhibitions, promotion materials, financial support of projects, etc.

7. Insufficient management at local level

8. Inadequate road infrastructure
9. Lack or inadequate condition of sanitary facilities at the entry to the country, as well as at filling stations, meant to serve groups of tourists

\section{Statements:}

6 medieval stone fortresses; over 1000 monuments of architecture protected by the state; over 15000 outdoor museums; 5698 protected monuments; 66 museums with 673 objects of patrimony

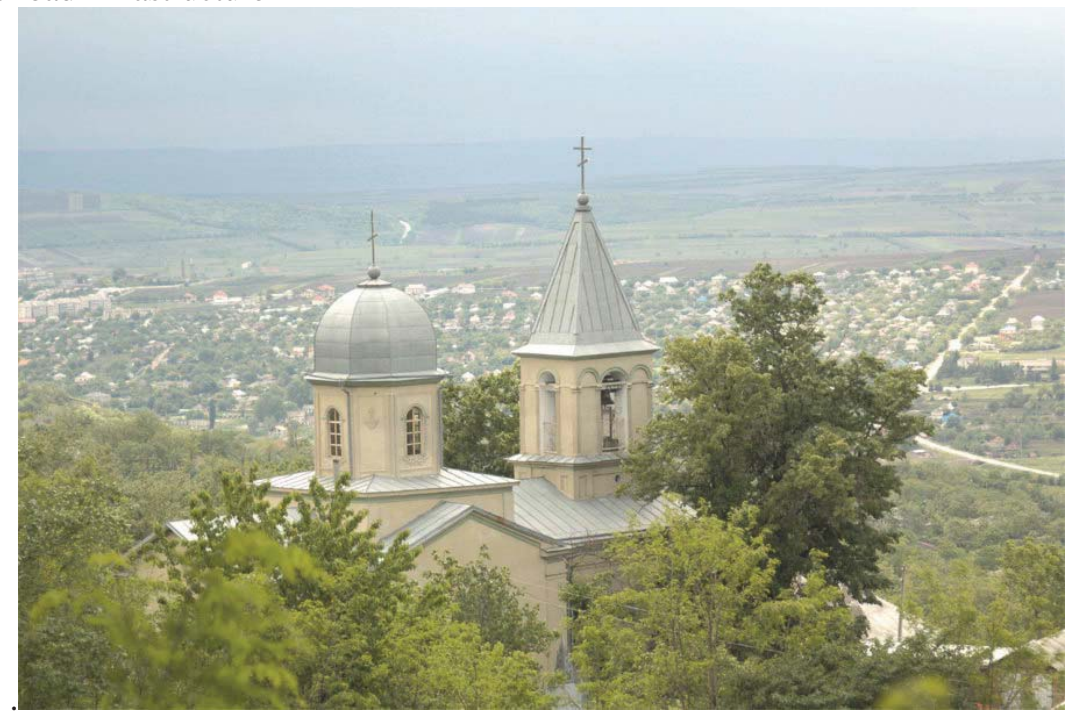

Vărzăreşti Monastery, Nisporeni region

UNESCO global heritage in the Republic of Moldova includes a single monument and two objects are in the examination list. The Republic of Moldova has ratified the UNESCO Convention on the protection of global cultural heritage in the year 2002.

The Struve geodetic arc is a network of 265 viewpoints made of stone cubes with two meter faces installed on a relative trajectory between Hammerfest (Norway) and Necrasovca-Veche (Ukraine). This network has been conceived for the determination of the shape and dimensions of Earth. The Struve geodetic arc underwent certain changes during the 40-years period, between 1816 and 1855 . Nowadays it is 2.820 kilometers long and has 34 observation points included into the UNESCO heritage since 2004. Objects in the examination list

The list below contains the monuments or places currently being examined but not yet registered as global heritage.

Chernozems of Balti steppe - Riscani district, Balti municipality 


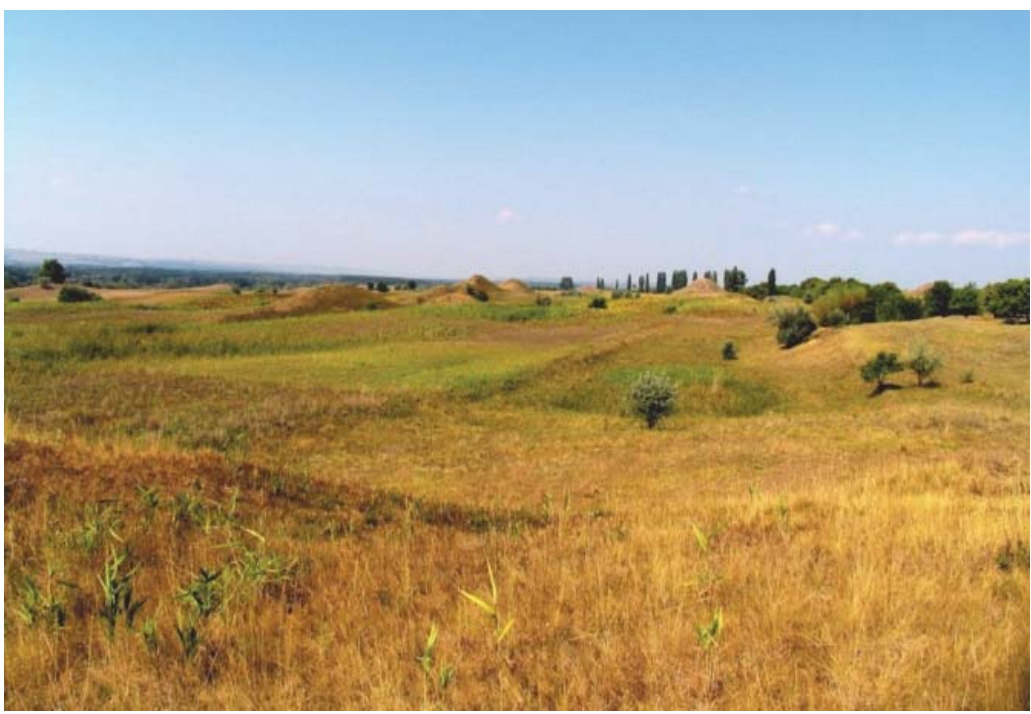

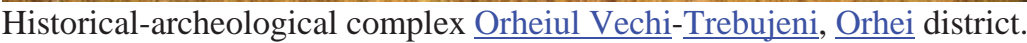

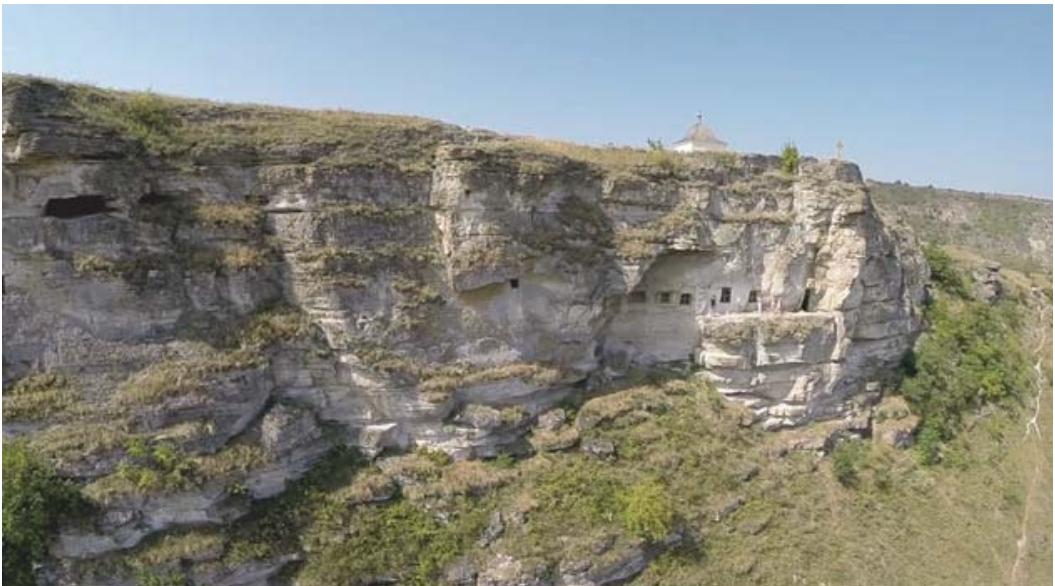

Not approved due to the failure of Moldavian party to comply with a set of requirements as to the maintenance and rehabilitation of monument.

Research suggestions:

To identify the main objects of patrimony for development.

To establish efficient collaboration between the proprietors or the administrators of tourist facilities and local authorities for the installation of signs, facilitation of access, arrangement of parking areas and structures for hosting the visitors.

To elaborate and implement a training program for the guides.

To organize trainings for the owners of tourist facilities as to the interpretation techniques boards, signs, brochures, audio materials; navigation.

To organize the edition of promotion materials in several internationally spoken languages.

To organize, with the support of the Department of Development of Tourism, training courses on the techniques and basic elements of designing promotion materials for tourists.

Construction and development of accommodation facilities for visitors in the zones of special cultural potential.

Modernization of accommodation facilities in monasteries and other cultural objects.

Modernization of parking bays with modern toilets, filling stations.

Creation of boarding possibilities at the boarding houses in the vicinity of religious objects.

Creation of a web site that would offer thorough 
information on the monasteries' services, as well as the pictures of their interesting sites and religious masses.

Creation of touristic programs that would allow visitors to take part in the monks' and nuns' daily activities as well as observe the religious masses.

Creation of a promotional video depicting the monasteries, and later on creation of a documentary about their historical heritage.
Location of Arts and Crafts schools on the monasteries' sites as well as shops selling their products.

Specialization of the monasteries in the areas they find more profitable (horticulture, fruitgrowing, vegetable-growing, forestry, vinification, sheep breeding, beekeeping, stitching, etc.)

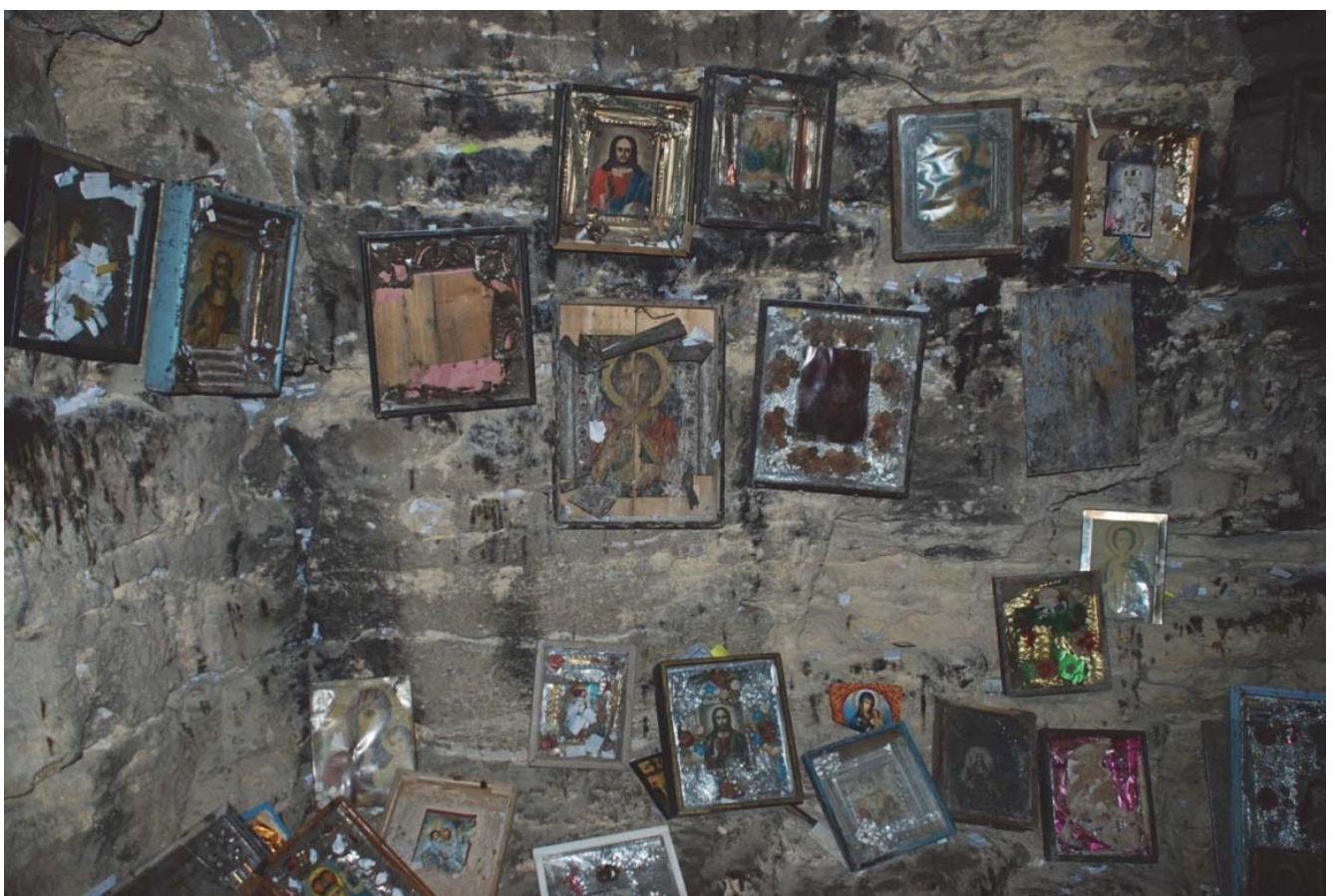

The interior of „Bunăvestire” Monastery, Străşeni region

Participation at fairs with the products of the tourism, for the tourist agencies practicing this monasteries' activities (vine, meat, vegetables, fruits, handmade gifts, etc.)

form of tourism, for the statistical analysis and Applied value: the results of this work are upheld by the value of useful statements, conclusions and recommendations: studies in the manner of cultural religious tourism, didactical staff in public and private education, editing of scientific-didactical works. The work may be useful for the students in mastering and prognoses, as well as for the determination of new development directions of tourism in the Republic of MoldovaScientific novelty and originality: the need to justify new forms of tourism and their integration into the offers of specialized tourist agencies; elaboration of development plans and diversification of tourist offers in collaboration with all institutions. 


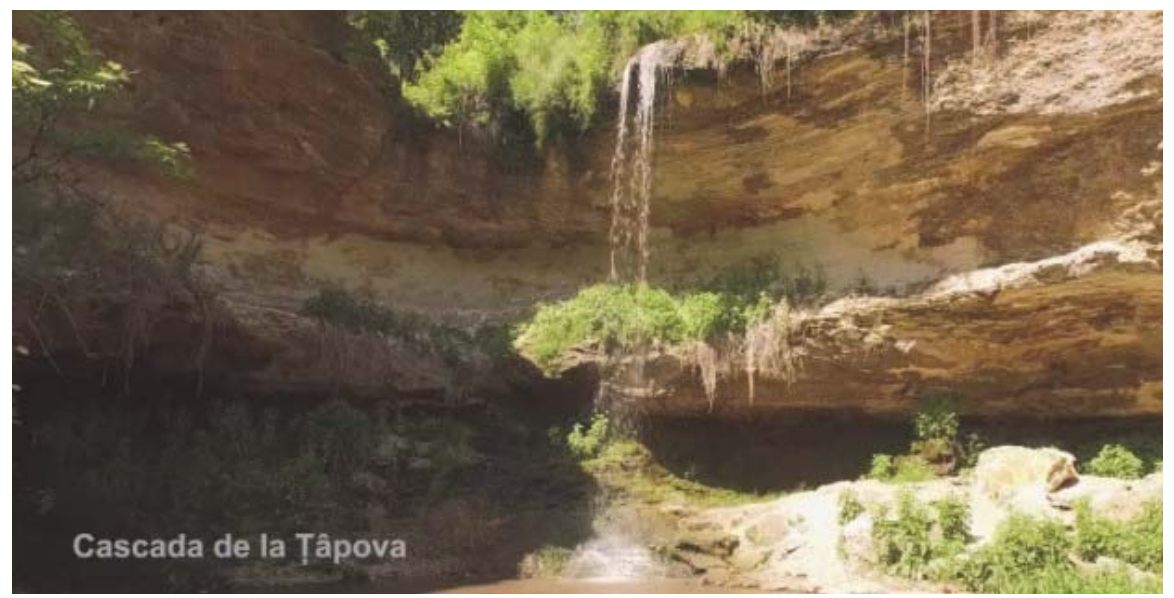

Conclusions and perspectives: the submitted Republic of Moldova" and can further be results represent a logical continuation of employed in the development of religious research performed under the Project ,Anti- tourism in Southeast Europe.

migration management in the rural sector of the

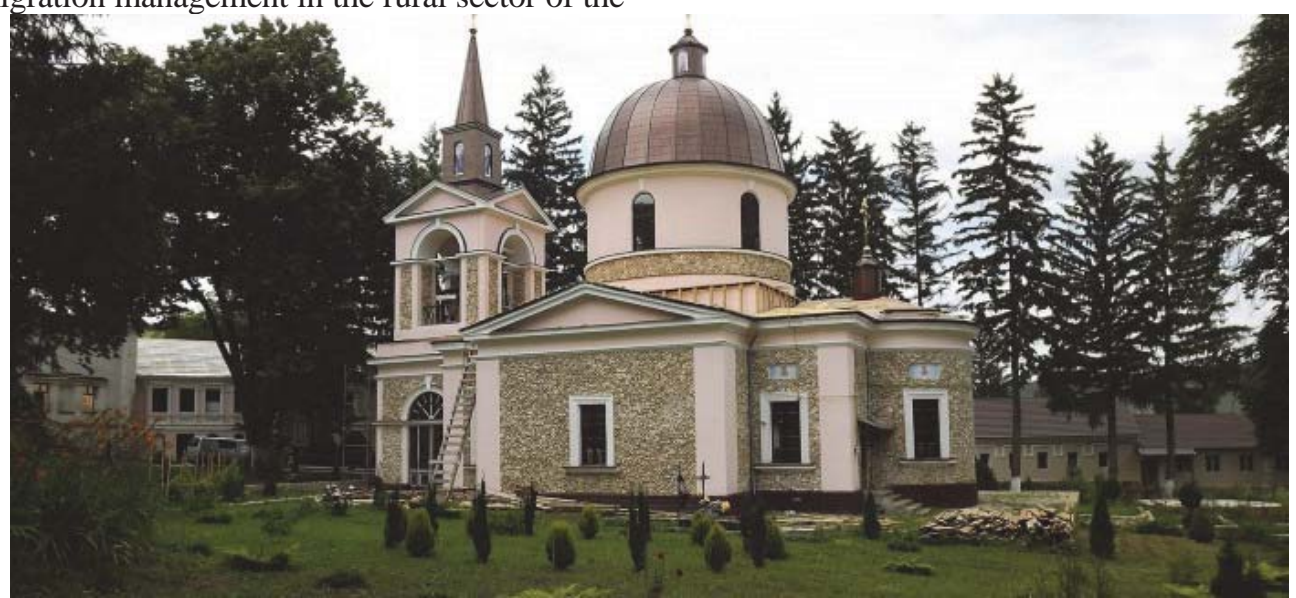

Hîrjauca Monastery, Călăraşi region

\section{References:}

[1] https://ro.wikipedia.org/

[2] Hotărîre nr.338 din 19 mai 2014 cu privire la aprobarea Strategiei de dezvoltare a turismului „Turism 2020” şi a Planului de acţiuni pentru implementarea acesteia în anii 2014-2016

[3] http://agora.md

[4] http://turism.gov.md/

[5] Apetri Niculina „Fundamentarea economică a strategiilor de dezvoltarea turismului cultural religios", cond. ştiinţific Elena Turcov, prof. univ. dr. hab. (teză de doctor în economie) 